\title{
AN INVESTIGATION OF THE RELATIONSHIP BETWEEN ORGANIZATIONAL CULTURE AND THE PERFORMANCE OF CONSTRUCTION ORGANIZATIONS
}

\author{
Sai On Cheung ${ }^{1}$, Peter S. P. Wong' ${ }^{2}$ Anna L. Lam ${ }^{3}$ \\ 1,2,3 Department of Civil and Architectural Engineering, City University of Hong Kong \\ ${ }^{2}$ School of Property, Construction and Project Management at RMIT University, \\ Melbourne, Australia \\ E-mails: ${ }^{1}$ SaiOn.Cheung@cityu.edu.hk; \\ 2peterspwong@rmit.edu.au (correspondingauthor); ${ }^{3}$ nana_lam@hotmail.com
}

Received 19 March 2011; accepted 08 July 2011

\begin{abstract}
The operation of organizations is very much influenced by their culture. Organizational culture (OC) has been defined as a pattern of basic assumptions that are manifested by the behavior of an organization. Positive OC is considered to be catalytic to performance enhancement. As construction aspires to be an efficient industry, this study aims to contribute in this regard by examining the relationship between organizational culture and the performance of construction organizations. Artifacts corresponding to OC identifiers and Performance indicators are short-listed from a literature review. These artifacts are arranged into constructs. The eight OC constructs are: Goal Clarity, Coordination and Integration, Conflict Resolution, Employee Participation, Innovation Orientation, Performance Emphasis, Reward Orientation and Team orientation. The performance indicator constructs are; Financial, Internal Business Process, Custom and Innovation \& Learning. The artifacts were elaborated and operationalized for data collection. The constructs, as well as the OC-Performance relationship framework, were then analyzed and tested using Structural Equation Modeling. Innovation was found to be the most critical OC as far as performance of construction organizations is concerned. In today's knowledge based society, innovative organizations have proved to be the performers. This timely finding highlights the need for a culture that fosters creativity and supports innovation.
\end{abstract}

Keywords: organizational culture, performance, construction, organizations, innovation, Structural Equation Model.

Reference to this paper should be made as follows: Cheung, S. O.; Wong, P. S. P.; Lam, A. L. 2012. An investigation of the relationship between organizational culture and the performance of construction organizations, Journal of Business Economics and Management 13(4): 688-704.

JEL Classification: C39, L20, L74.

\section{Introduction}

Construction aspires to be an efficient industry (Egan 1998; CIRC 2001). Some of the well-known barriers include, inter alia, confrontational contracting behavior, a lack of innovation, and indifference to research and development (Egan 1998; Zeng et al. 2009). 
Some notable successful construction organizations have insightfully departed from the conventional 'construction only' business model. These forward-looking construction organizations have in fact realized their potential by departing from entrenched practices. This move involves a form of cultural change and can be risky. However, changes have brought life to these organizations by widening their scope of operation and markets. In fact, organizational culture (OC) has been identified as one of the essential factors that affect the efficiency and productivity of a firm (Alas et al. 2009). It has been strongly advocated that through cultivating and maintaining a culture that is conducive to stimulating performance improvement, the efficiency of firms and ultimately the construction industry can be improved (Gordon, DiTomaso 1992). Successful project delivery relies on the concerted effort of all those involved and construction organizations are responsible for realizing designs into physical objects. The impact of their performance on projects is particularly apparent because of their front line positions. In this regard, this study aims to investigate the relationship between organizational culture (OC) and the performance of construction organizations. Furthermore, it is also proposed that further studies of organizational culture involving other stakeholders within the construction supply chain would extend the understanding of organizational culture in construction, although these are beyond the scope of the present study.

The paper is organized as follows. Firstly, the impact of organizational culture on performance is reviewed. Secondly, identifiers of OC and performance indicators of construction organizations are listed. Thirdly, a framework describing the relationship between OC and construction organizations' performance is proposed. Fourthly, an empirical test of this OC-Performance relationship framework is presented. Finally, the findings and their implications for project management are discussed.

\section{Organizational culture and performance}

The concept of organizational culture has become a major theme of management studies since the mid-1980s. One of the influential works is the Organizational Culture and Leadership model developed by Schein (1985). Organizational culture is defined as a pattern of basic assumptions - invented, discovered, or developed by a given group as it learns to cope with its problems of external adaptation and internal integration - that has worked well enough to be considered valid and, therefore, to be taught to new members as the correct way to perceive, think and feel in relation to those problems (Schein 1985). This definition reveals, by its focus on assumptions, that when considering culture we are dealing with implicit assumptions as much as explicit or overt behavior. A 'strong' culture is one where the implicit and explicit assumptions are in harmony and is deeply entrenched and change-resistant. Similarly, Cole (1997) considered culture as a twotiered set of "shared values, norms and beliefs within an organization". On the surface it is the explicit culture, which manifests itself in the 'official' organizational structure and communications. Beneath the surface it is the implicit culture that management and staff consider really important. Moreover, Smircich (1983) defined OC as the social glue that holds members in an organization together. It expresses the social ideals, values and beliefs that members of an organization come to share. These values or patterns of belief are manifested in symbolic devices such as myths, rituals, stories, legends, and special- 
ized language (Smircich 1983). Schein (1985) also pointed out that there may be several cultures operating within an organization: a managerial culture, various occupationallybased cultures in functional units, group cultures based on geographical proximity, and worker cultures based on shared hierarchical experiences. The organization as a whole will have an overall culture "if that whole organization has a significant shared history". Organizational culture therefore has several important functions. First, it conveys a sense of identity for organization members. Second, it facilitates the generation of commitment to something larger than the self. Third, it enhances system stability. And fourth, organizational culture serves as a sense-making device that can guide and shape members' behavior (Peters, Waterman 1982; Hofstede 2001; Alas et al. 2009). Taking into account contextual factors, positive and enduring OC therefore can have a positive effect on individual and organizational performance (Denison 1990). With these propositions, research into the relationship between organizational culture and performance has surged (Denison 1990; Ankrah, Langford 2005; Cheung et al. 2010).

In construction, Bresnen and Marshall (2000) used a set of cultural parameters to identify business excellence in construction organizations. Employing a trait-based organizational culture scale, Liu (1999) found that job satisfaction amongst real estate professionals could be enhanced by organizational cultures that are i) people-oriented, ii) team-oriented and iii) supportive and emphasize free flow of information. However, the effect of culture on organization's performance was not discussed. Ankrah and Langford (2005) articulated the organizational culture characterizing architectural firms and construction organizations. The differences in the cultural dimensions help to explain the confrontational environment in construction contracting. Nevertheless, perceptive views from other major groups of stakeholders such as the surveying and engineering consultants and the subcontractors were not studied. Employing the Organizational Culture Assessment Instrument (OCAI) developed by Cameron and Quinn (1999), Zhang and Liu (2006) proposed a behavior-outcome model in analyzing the organizational culture profiles of construction enterprises in China. Based on a case study of two Dutch contractors, Caerteling et al. (2006) found that dynamic and innovation oriented contractors adopt more progressive policies in conducting their business. The study from Cheng and Liu (2007) also identified a significant correlation between success in implementing Total Quality Management and the clan culture of construction firms. More recently, Ozorhon et al. (2008) examined the extent to which the performance of an international joint venture (IJV) is affected by the organizational cultures of the collaborating firms. These studies collectively identified that performance improvement in an organization is a result of successfully translating values and beliefs into policies and practices. Despite the OC assessment tools adopted in the above studies were not construction specific, the related findings studies indicate a close relationship between OC and performance. Nonetheless, the nature of such relationship remains unanswered in the construction context and this deserves further investigation. The study reported in this paper aims to fill this research gap. For this study, the hypothesis therefore is:

H1: The performance of construction organizations is positively affected by their organizational cultures. 
To test this hypothesis, a framework describing the relationship between identifiers of organizational culture and performance indicators is analyzed using Structural Equation Modeling.

\subsection{Identifiers of organizational culture}

Organizational culture implies the existence of certain closely associated and interdependent dimensions (Peters, Waterman 1982). Ankrah and Langford (2005) preferred the use of dimensions to describe OC because of its flexibility to reflect the values being assessed. A list of dimensions can be compiled to reflect the various perspectives adopted by different researchers. However, having too many dimensions may make the framework lose meaning as attention may be diverted to the fine and subtle differences among dimensions (Hofstede 2001). The identifiers of organizational culture suggested by different researchers are summarized in Table 1 . It is proposed that organizational culture can be identified by eight cultural dimensions; Goal Clarity (GC), Coordination and Integration (CI), Conflict Resolution (CR), Employee Participation (EP), Innovation Orientation (IO), Performance Emphasis (PE), Reward Orientation (RO) and Team Orientation (TO).

Table 1. Identifiers of Organizational Culture (OC)

\begin{tabular}{|c|c|c|c|c|c|c|c|c|}
\hline \multirow{2}{*}{$\begin{array}{c}\text { Organizational } \\
\text { Culture (OC) } \\
\text { Identifiers } \\
\end{array}$} & \multirow{2}{*}{ OC operational statements } & \multirow{2}{*}{$\begin{array}{l}\text { Mean } \\
\text { Score }\end{array}$} & \multicolumn{6}{|c|}{ References } \\
\hline & & & A B & $\mathrm{C}$ & D & $\mathrm{E}$ & $\mathrm{F}$ & G \\
\hline \multirow{3}{*}{$\begin{array}{l}\text { Goal Clarity } \\
\text { (GC) }\end{array}$} & $\begin{array}{l}\text { How well the employees know what they } \\
\text { need to do to succeed in the long run (GC1) }\end{array}$ & 5.12 & * & $*$ & & $*$ & $*$ & * \\
\hline & $\begin{array}{l}\text { The extent to which organization's goals } \\
\text { is reasonably and clearly set with regular } \\
\text { reviews (GC2) }\end{array}$ & 4.91 & * & $*$ & & $*$ & $*$ & $*$ \\
\hline & $\begin{array}{l}\text { The extent to which employees' effort is } \\
\text { directed to accomplish the organizations' } \\
\text { goal (GC3) }\end{array}$ & 4.73 & * & $*$ & & $*$ & $*$ & $*$ \\
\hline \multirow{3}{*}{$\begin{array}{l}\text { Coordination } \\
\text { and } \\
\text { Integration } \\
\text { (CI) }\end{array}$} & $\begin{array}{l}\text { The effectiveness of resolving problems } \\
\text { between departments (CI1) }\end{array}$ & 4.34 & * & $*$ & $*$ & $*$ & * & $*$ \\
\hline & $\begin{array}{l}\text { The extent to which sharing of information } \\
\text { between departments is encouraged (CI2) }\end{array}$ & 4.79 & * & $*$ & $*$ & $*$ & $*$ & $*$ \\
\hline & $\begin{array}{l}\text { The extent to which cooperation and } \\
\text { assistance across department is encouraged } \\
\text { (CI3) }\end{array}$ & 4.69 & * & $*$ & $*$ & $*$ & $*$ & * \\
\hline \multirow{3}{*}{$\begin{array}{l}\text { Conflict } \\
\text { Resolution } \\
\text { (CR) }\end{array}$} & $\begin{array}{l}\text { The extent to which the employees accept } \\
\text { criticism or negative feedback without } \\
\text { becoming defensive (CR1) }\end{array}$ & 4.27 & & $*$ & & & & $*$ \\
\hline & $\begin{array}{l}\text { The extent to which the employees are } \\
\text { encouraged to share the responsibility of } \\
\text { things that go wrong in their work group } \\
\text { (CR2) }\end{array}$ & 4.42 & & $*$ & & & & $*$ \\
\hline & $\begin{array}{l}\text { The atmosphere of trust in this organization } \\
\text { (CR3) }\end{array}$ & 4.40 & & $*$ & & & & . \\
\hline
\end{tabular}


End of Table 1

\begin{tabular}{|c|c|c|c|c|c|c|c|c|c|}
\hline \multirow{2}{*}{$\begin{array}{c}\text { Organizational } \\
\text { Culture (OC) } \\
\text { Identifiers }\end{array}$} & \multirow[b]{2}{*}{ OC operational statements } & \multirow{2}{*}{$\begin{array}{l}\text { Mean } \\
\text { Score }\end{array}$} & \multicolumn{7}{|c|}{ References } \\
\hline & & & A & B & $\mathrm{C}$ & $\mathrm{D}$ & $\mathrm{E}$ & $\mathrm{F}$ & G \\
\hline \multirow{3}{*}{$\begin{array}{l}\text { Employee } \\
\text { Participation } \\
\text { (EP) }\end{array}$} & $\begin{array}{l}\text { The extent to which employees are } \\
\text { encouraged to have some input on decisions } \\
\text { that affect their work (EP1) }\end{array}$ & 4.47 & & $*$ & $*$ & & $*$ & $*$ & $*$ \\
\hline & $\begin{array}{l}\text { The extent to which organizations allow } \\
\text { employees to participate in the decision- } \\
\text { making process (EP2) }\end{array}$ & 4.40 & & * & $*$ & & $*$ & * & $*$ \\
\hline & $\begin{array}{l}\text { The extent to which employees are } \\
\text { consulted in respect of decisions regarding } \\
\text { what the organization plans to do (EP3) }\end{array}$ & 3.99 & & $*$ & $*$ & & $*$ & $*$ & * \\
\hline \multirow{4}{*}{$\begin{array}{l}\text { Innovation } \\
\text { Orientation } \\
\text { (IO) }\end{array}$} & $\begin{array}{l}\text { The extent to which the organization helps } \\
\text { employees to obtain the resources necessary } \\
\text { to implement their innovative (IO1) }\end{array}$ & 4.58 & $*$ & & $*$ & & & & * \\
\hline & $\begin{array}{l}\text { The extent to which the employees are } \\
\text { encouraged to search for better ways of } \\
\text { getting the job done (IO2) }\end{array}$ & 4.53 & $*$ & & $*$ & & $*$ & & $*$ \\
\hline & $\begin{array}{l}\text { The extent to which the employees are } \\
\text { encouraged to be creative and innovative } \\
\text { (IO3) }\end{array}$ & 4.55 & $*$ & & & & & & $*$ \\
\hline & $\begin{array}{l}\text { The willingness of the organization to take } \\
\text { reasonable risk in response to changes of } \\
\text { business environment (IO4) }\end{array}$ & 4.35 & $*$ & & & & & & $*$ \\
\hline \multirow{3}{*}{$\begin{array}{l}\text { Performance } \\
\text { Emphasis } \\
\text { (PE) }\end{array}$} & $\begin{array}{l}\text { The extent to which the employees are } \\
\text { coached to improve their skills so they can } \\
\text { achieve higher levels of performance (PE1) }\end{array}$ & 4.71 & $*$ & $*$ & $*$ & & $*$ & $*$ & $*$ \\
\hline & $\begin{array}{l}\text { The establishment of a set of performance } \\
\text { standards for employees (PE2) }\end{array}$ & 4.45 & $*$ & $*$ & $*$ & & $*$ & $*$ & $*$ \\
\hline & $\begin{array}{l}\text { The extent to which the organization } \\
\text { emphasizes on delivering products with } \\
\text { good quality (PE3) }\end{array}$ & 5.14 & $*$ & $*$ & $*$ & & $*$ & $*$ & * \\
\hline \multirow{4}{*}{$\begin{array}{l}\text { Reward } \\
\text { Orientation } \\
\text { (RO) }\end{array}$} & The extent to of equitable rewards (RO1) & 4.32 & & $*$ & & & $*$ & * & * \\
\hline & $\begin{array}{l}\text { The level of which performance appraisals } \\
\text { are used as the basis to reward employees } \\
\text { (RO2) }\end{array}$ & 4.29 & & $*$ & & & $*$ & * & * \\
\hline & $\begin{array}{l}\text { The level of which emphasis is placed on } \\
\text { rewarding employees for success rather than } \\
\text { punishing them for failure (RO3) }\end{array}$ & 4.51 & & $*$ & & & $*$ & $*$ & * \\
\hline & $\begin{array}{l}\text { The extent which the employees are } \\
\text { adequately recognized and rewarded (RO4) }\end{array}$ & 4.46 & & $*$ & & & $*$ & * & * \\
\hline \multirow{3}{*}{$\begin{array}{l}\text { Team } \\
\text { Orientation } \\
\text { (TO) }\end{array}$} & $\begin{array}{l}\text { The extent to which the organization } \\
\text { emphasizes on team contributions rather } \\
\text { then individual contributions (TO1) }\end{array}$ & 4.74 & & & $*$ & * & $*$ & & * \\
\hline & $\begin{array}{l}\text { The extent to which the organizations } \\
\text { emphasizing on building cohesive, } \\
\text { committed teams of people (TO2) }\end{array}$ & 4.58 & & & * & $*$ & $*$ & & $*$ \\
\hline & $\begin{array}{l}\text { The extent to which members work as a } \\
\text { team and exchange opinions and ideas } \\
\text { (TO3) }\end{array}$ & 4.35 & & & $*$ & $*$ & $*$ & & * \\
\hline
\end{tabular}

References: (A) Peters and Waterman 1982; (B) Cameron and Quinn 1999; (C) Denison 1990; (D) Hofstede 2001; (E) Ankrah and Langford 2005; (F) Zhang and Liu 2006; (G) Cheung et al. 2010 
For the purpose of this study, it is also necessary to devise operation statements to characterize the respective $\mathrm{OC}$ dimensions. These become the measurement statements to be used to collect data for the testing of the relationship framework. This methodology has been successfully used by Butler (1991) in measuring trust between managers and subordinates; and Cummings and Bromiley (1996) in measuring trust between units of an organization.

\subsection{Performance indicators of construction organizations}

The use of indicators to evaluate organizational performance is very common (Xiao, Proverbs 2003). In construction, compliance with predetermined criteria regarding time, cost and quality are the key indicators typically used (Xiao, Proverbs 2003). In 2000, the KPI Working Group in the United Kingdom developed Key Performance Indicators (KPI) and these have then become one of the most popular performance evaluation frameworks in use. Under KPI, construction organizations' performance is evaluated along a number of dimensions, including: (1) Profitability, (2) Productivity, (3) Return on capital employed, (4) Return on value added, (5) Interest cover, (6) Return on investment, (7) Ratio of value added, (8) Repeat business, (9) Outstanding money and (10) Time taken to reach final account. Notwithstanding its popularity, KPI seems to be more appropriate in assessing performance at a project level (Kagioglou et al. 2001). Furthermore, performance should not only be singularly assessed by the achievement of measurable benefits, but also by the effectiveness of contractors in sustaining performance improvements, such as their competence in addressing risk and its consequences (Law, Chuah 2004), learning from experience (Wong et al. 2008) and generating innovative ideas (Kagioglou et al. 2001). To this end, Bayliss et al. (2004) critically compared the strengths and weaknesses of a number of performance measurement systems in construction, including the KPI, the European Foundation for Quality Management Excellence Model (EFQM) and the Balanced Scorecard (BSC). They suggested that the BSC framework developed by Kaplan and Norton (1992) provides a more holistic assessment of performance that goes beyond the project level. Mohamed (2003) indicated the word 'Balanced' in BSC represents equal emphasis on both tangible and intangible elements representing the core values of the company. The 'Scorecard' records results systematically and indicates the successfulness in adopting appropriate strategies to address shortterm and long-term goals (Amaratunga et al. 2001). The BSC framework also enables the company's core values and strategies to be articulated and linked (Mohamed 2003). With reference to the work of Kaplan and Norton (1992), four strategic dimensions can be used to measure organizational performance: Financial, Customer, Internal Business Process, and Learning and Growth. In construction, a number of studies have used the Balanced Scorecard (BSC) framework to evaluate construction organizations' performance (Kagioglou et al. 2001; Mohamed 2003; Lo et al. 2006). For example, Mohamed (2003) applied the BSC approach to develop construction safety performance indicators. Four strategic dimensions for evaluating organizations' construction safety performance were proposed: (1) Management, (2) Operation, (3) Customer and (4) Learning. Based on case studies conducted in the United Kingdom, Kagioglou et al. (2001) proposed 
that construction project performance should be evaluated under the headings of Financial, Internal Business Processes and Customer perspectives. To embrace the holistic approach of the BSC framework, the 'Innovation and Learning' dimension is also included. As a result, for this study, the four key performance indicators of construction organizations used are: Financial (FIN), Internal Business Processes (IBP), Customer (CUS) and Innovation and Learning (INL). The operation statements of these indicators are listed in Table 2.

Table 2. Performance indicators of construction organizations

\begin{tabular}{|c|c|c|c|c|c|}
\hline \multirow{2}{*}{$\begin{array}{l}\text { Performance } \\
\text { Indicators }\end{array}$} & \multirow{2}{*}{ Performance operational statements } & \multirow{2}{*}{$\begin{array}{l}\text { Mean } \\
\text { Scores }\end{array}$} & \multicolumn{3}{|c|}{ References } \\
\hline & & & $\mathrm{H}$ & I & $\mathrm{J}$ \\
\hline \multirow[t]{4}{*}{ Financial (FIN) } & $\begin{array}{l}\text { Meeting predetermined goals on } \\
\text { profitability (FIN1) }\end{array}$ & 4.63 & $*$ & $*$ & \\
\hline & $\begin{array}{l}\text { Meeting predetermined goals on revenue } \\
\text { growth (FIN2) }\end{array}$ & 4.68 & $*$ & $*$ & \\
\hline & $\begin{array}{l}\text { Maintaining competitiveness in the market } \\
\text { (FIN3) }\end{array}$ & 4.88 & $*$ & $*$ & \\
\hline & $\begin{array}{l}\text { Meeting predetermined goals on increasing } \\
\text { shareholders returns (FIN4) }\end{array}$ & 4.73 & $*$ & $*$ & \\
\hline \multirow[t]{4}{*}{$\begin{array}{l}\text { Internal Business } \\
\text { Processes (IBP) }\end{array}$} & $\begin{array}{l}\text { Meeting predetermined goals on quality } \\
\text { level (IBP1) }\end{array}$ & 4.84 & $*$ & $*$ & \\
\hline & $\begin{array}{l}\text { Meeting predetermined goals on cost } \\
\text { control (IBP2) }\end{array}$ & 4.65 & $*$ & $*$ & \\
\hline & $\begin{array}{l}\text { Enhancing competence in identifying } \\
\text { company's goals (IBP3) }\end{array}$ & 4.71 & $*$ & $*$ & \\
\hline & $\begin{array}{l}\text { Enhancing competence in maintaining the } \\
\text { process of achieving the predetermined } \\
\text { goals (IBP4) }\end{array}$ & 4.75 & $*$ & $*$ & \\
\hline \multirow[t]{4}{*}{ Customer (CUS) } & $\begin{array}{l}\text { Obtaining feedback from customers } \\
\text { (CUS1) }\end{array}$ & 4.86 & $*$ & $*$ & \\
\hline & $\begin{array}{l}\text { Enhancing competence in satisfying } \\
\text { customers' needs (CUS2) }\end{array}$ & 4.76 & $*$ & $*$ & \\
\hline & $\begin{array}{l}\text { Enhancing competence in keeping existing } \\
\text { customers (CUS3) }\end{array}$ & 4.90 & $*$ & $*$ & \\
\hline & $\begin{array}{l}\text { Meeting predetermined goals on company } \\
\text { vision about customer service (CUS4) }\end{array}$ & 4.67 & $*$ & $*$ & \\
\hline \multirow[t]{4}{*}{$\begin{array}{l}\text { Innovation and } \\
\text { Learning (INL) }\end{array}$} & $\begin{array}{l}\text { Providing adequate training to employees } \\
\text { (INL1) }\end{array}$ & 4.85 & $*$ & & $*$ \\
\hline & $\begin{array}{l}\text { Providing adequate review of practice to } \\
\text { adapt to market change (INL2) }\end{array}$ & 4.72 & $*$ & & $*$ \\
\hline & $\begin{array}{l}\text { Enhancing competence in driving } \\
\text { innovative ideas from employees (INL3) }\end{array}$ & 4.49 & & & $*$ \\
\hline & $\begin{array}{l}\text { Enhancing competence in transforming } \\
\text { employees' innovative ideas to decisions } \\
\text { (INL4) }\end{array}$ & 4.40 & & & $*$ \\
\hline
\end{tabular}




\section{A framework relating organizational culture and performance}

Based on the discussion in the fore-going two sections, an OC-Performance relationship framework arranged in a Structural Equation Modelling format is proposed (Figure 1). The arrows in the figure represent the direction of the hypothesized influence. For example, GC can be identified by the attribute: 'how well the employees know what they need to do to succeed in the long run' (GC1). Hence an arrow extends from ' $\mathrm{GC}$ ' to ' $\mathrm{GC1}$ '.

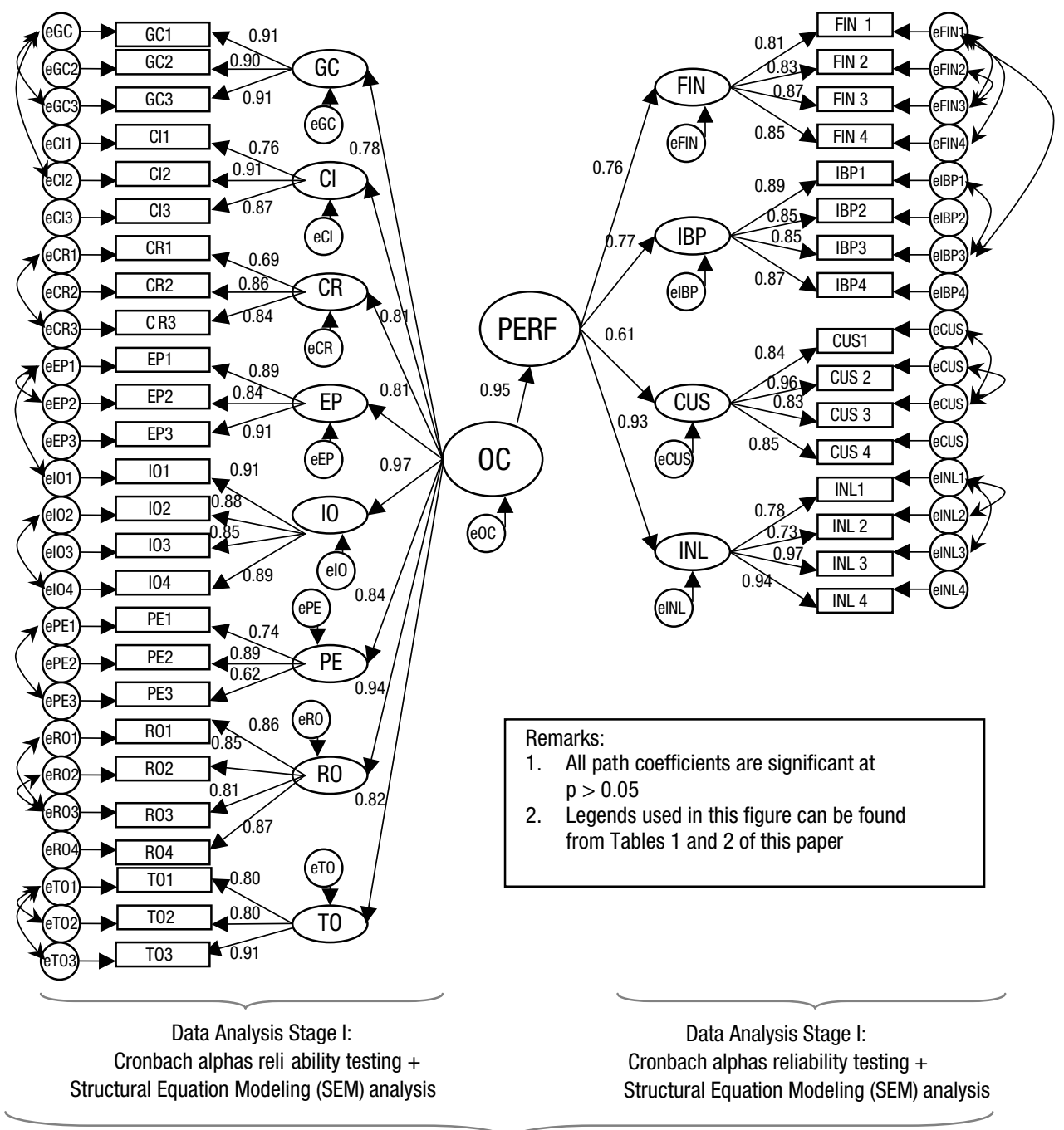

Data Analysis Stage II:

Structural Equation Modeling (SEM) analysis

Fig. 1. Final SEM of the OC-Performance relationship framework 
In this study, Structural Equation Modeling is proposed to investigate i) the relationship between OC identifiers and their operators; ii) the relationship between performance indicators and their operators and iii) the relationship between OC and performance. As such, two stages of data analysis were performed. The first stage involved the checking of construct reliability and inter-relationships. The checking of construct reliability is done to validate the reliability of representing a latent variable by its observed variables (also called internal consistency). This check can be done by conducting Cronbach alpha reliability testing. The alpha ranges from 0 to 1 . The higher the alpha value, the greater is the internal consistency of the construct. A value from 0.6 to 0.7 is regarded as "sufficient" and a value greater than 0.7 is regarded as "good" (Sharma 1996). The construct inter-relationships were then checked using Pearson correlation analysis with the aim of validating the proposed inter-relationships among constructs. Both the Cronbach alpha reliability testing and the Pearson correlation analysis were done using Statistical Package for Social Science (SPSS) Version 11.

The second stage involved analyzing the overall fitness of the model by investigating the fitness of the hypothesized relationships using Structural Equation Modeling (SEM) (Jöreskog, Sörbom 1996). SEM is a useful tool in theory development because it allows the researcher to propose and subsequently test propositions about the interrelationships among variables in a multivariate setting (Hair et al. 1998).

SEM integrates the analytical functions of both multiple regression analysis (MRA) and confirmatory factor analysis (Arbuckle, Wothke 1999; Molenaar et al. 2000). SEM can be used to represent, estimate and validate linear relations among observable and latent variables of a hypothesized network (Molenaar et al. 2000). Hair et al. (1998) described SEM as a multivariate technique for estimating a series of inter-related and inter-dependent relationships simultaneously. Molenaar et al. (2000) emphasized that the use of SEM can reduce the shortcomings of the MRA because the technique also accounts for errors in measurement when a large number of variables is involved. Thus, a more accurate representation of the overall results can be obtained from a SEM framework (Arbuckle, Wothke 1999). A computer package called "Analysis of Moment Structures 5.0" (AMOS) was used for the SEM analysis. The fitness of the relationship frameworks and the overall structural model was assessed using four Goodness of Fit (GOF) indices available from AMOS: Root Means Square Error of Approximation (RMSEA), Goodness-of-fit index (GFI), Tucker-Lewis index (TLI) and Normal fit index (NFI).

The recommended acceptance thresholds of the GOF indices are shown in Table 3. If these are not achieved, model refinements are required. However, model refinements must be done carefully and with sound theoretical justifications. Thus a modification should only be effected if it makes good sense theoretically or practically (Arbuckle, Wothke 1999). AMOS offers modification suggestions for GOF value improvements. The suggestions include revising the relationship paths and adding covariance error paths between observed and latent variables (Molenaar et al. 2000). 
Table 3. Goodness-of-fit (GOF) measures recommended levels and results (table format adopted from Molenaar et al. 2000)

\begin{tabular}{lllcc}
\hline \multirow{2}{*}{$\begin{array}{l}\text { Goodness-of-fit (GOF) } \\
\text { measure }\end{array}$} & \multicolumn{1}{c}{$\begin{array}{c}\text { Recommended } \\
\text { acceptance thresholds } \\
\text { of the GOF indices }\end{array}$} & $\begin{array}{c}\text { Stage IA: } \\
\text { OC }\end{array}$ & $\begin{array}{c}\text { Stage IB: } \\
\text { Performance }\end{array}$ & $\begin{array}{c}\text { Stage II: OC- } \\
\text { Performance }\end{array}$ \\
\cline { 3 - 5 } $\begin{array}{l}\text { Goodness-of-fit index } \\
\text { (GFI) }\end{array}$ & $\begin{array}{l}\text { 0 (No fit) to } 1 \\
\text { (Perfect fit) }\end{array}$ & 0.84 & 0.86 & 0.82 \\
\hline RMSEA & $\begin{array}{l}<0.05 \text { indicates very } \\
\text { good fit }- \text { threshold } \\
\text { level is 0.10 }\end{array}$ & 0.04 & 0.07 & 0.07 \\
\hline Tucker-Lewis index & $\begin{array}{l}\text { 0 (No fit) to 1 } \\
\text { (Perfect fit) }\end{array}$ & 0.98 & 0.97 & 0.89 \\
\hline NLI) & $\begin{array}{l}\text { 0 (No fit) to 1 } \\
\text { (Perfect fit) }\end{array}$ & 0.90 & 0.92 & 0.88 \\
\hline
\end{tabular}

\section{Testing the frameworks}

A questionnaire was used for data collection. The questionnaire has three parts: Part 1 - Personal Information, Part 2 - Identification of OC and Part 3 - Performance Assessment. The questions in Part 1 were aimed at soliciting personal information from the respondents. Part 2 includes 26 OC operational statements summarized in Table 1. Respondents were asked to express their degree of agreement on the use of these identifiers to represent the organizational culture of their companies, using a 7-point Likert scale. Part 3 includes 16 questions developed from the four performance indicators as summarized in Table 2. The respondents were requested to evaluate their company's performance using a 7-point Likert scale.

The questionnaire was sent to construction organizations in Hong Kong. The target respondents were randomly selected from the lists of construction organizations from the official webpage of The Hong Kong Construction Association (HKCA) and the latest Hong Kong Builder's Directory. These two sources provide the most comprehensive list of construction organizations in Hong Kong. The target respondents include directors, project managers and professional grade staff (including engineers and surveyors). A total of 185 questionnaires were sent and 109 were completed and returned by the respondents. Six replies were excluded for incompleteness. As a result, 103 valid responses, representing a response rate of $55.7 \%$, were used for the analysis. Among the valid responses, over $70 \%$ of the respondents had over 10 years working experience.

\section{Findings and discussions}

\subsection{Descriptive statistics}

With reference to Tables 1 and 2, it can be seen that the mean scores for the OC statements were higher than the mid-point of the 7-point scale (i.e. 3.5). This generally suggests that the respondents agreed that the eight OC identifiers and the respec- 
tive operational statements can be used to describe the organizational culture of their organizations. Furthermore, the mean scores for the performance operational statements ranged from 4.40 to 4.90 suggesting that the respondents generally rated their company's performance as above average.

\subsection{Stage I: testing the validity of the $\mathrm{OC}$ and performance constructs}

To ensure the appropriateness of groupings of the operational statements for organizational culture and performance indicators, internal consistency of the constructs was checked. Table 4 details the results of the Cronbach alphas reliability tests. All groupings had Cronbach alpha values above 0.8, suggesting that the operational statements are significantly related to the respective OC identifiers and performance indicators. Hence, all the operational statements and their respective constructs are retained.

Table 4. Results of Cronbach alphas reliability testing

\begin{tabular}{lc}
\hline \multicolumn{1}{c}{ OC } & Cronbach Alpha Value \\
\hline Goal Clarity (GC) & 0.90 \\
Coordination and Integration (CI) & 0.88 \\
Conflict Resolution (CR) & 0.84 \\
Employee Participation (EP) & 0.89 \\
Innovation Orientation (IO) & 0.93 \\
Performance Emphasis (PE) & 0.81 \\
Reward Orientation (RO) & 0.92 \\
Team Orientation (TO) & 0.880 \\
\hline \multicolumn{1}{c}{ Performance } & 0.91 \\
\hline Financial (FIN) Cronbach Alpha Value \\
Internal Business Processes (IBP) & 0.92 \\
Customer (CUS) & 0.93 \\
Innovation and Learning (INL) & 0.91 \\
\hline
\end{tabular}

The validity of the OC and Performance constructs were then tested by using SEM analyses. Considering the modifications suggested by AMOS, if necessary, refinements of the models can be made. No elimination of statements or constructs was suggested. This indicates that the constructs and relationship paths proposed in the conceptual model generally passed the statistical validity test. The suggested changes involved adding correlation paths between the error terms of the operational statements within the same construct (Arbuckle, Wothke 1999). The GOF indices for the final OC and Performance constructs were satisfactory (results refer to Table 3).

\subsection{Stage II: The OC-Performance relationship framework}

At this stage of the analysis, the refined constructs of OC and Performance were combined to form the OC-Performance relationship structural equation model. The validity of the structural model was then assessed as afore-described. Model refinements were performed until all GOF measures achieved the recommended levels (Molenaar et al. 
2000; Wong et al. 2008). The set of model fit parameter values of the final SEM were RMSEA $=0.07$; GFI $=0.82$; TLI $=0.89$ and NFI $=0.88$. The standardized regression weights and the GOF indices of the final SEM are presented in Figure 1 and Table 3 respectively.

To summarize, all the relationship paths as specified in the OC-Performance SEM (refer to Figure 1) were found to be positive and significant at $\mathrm{p}<0.05$. The SEM results suggest that:

1. OC can be represented by the eight OC identifiers as shown in Table 1: Goal clarity $(\mathrm{GC})$ (standardized regression weight $=0.77)$, Coordination \& Integration $(\mathrm{CI})$ (standardized regression weight $=0.78$ ), Conflict Resolution $(\mathrm{CR})$ (standardized regression weight $=0.81)$, Employee Participation $(\mathrm{EP})$ (standardized regression weight $=0.81)$, Innovation Orientation $(\mathrm{IO})$ (standardized regression weight $=$ 0.97), Performance Emphasis $(\mathrm{PE})$ (standardized regression weight $=0.84$ ), Reward Orientation $(\mathrm{RO})$ (standardized regression weight $=0.94)$ and Team Orientation $(\mathrm{TO})$ (standardized regression weight $=0.82$ ).

2. Construction organization's performance can be evaluated using the four strategic dimensions in the BSC framework: Financial (FIN) (standardized regression weight $=0.76)$, Internal Business Processes $(\mathrm{IBP})$ (standardized regression weight $=0.77)$, Customer $($ CUS $)$ (standardized regression weight $=0.61)$ and Innovation and Learning $(\mathrm{INL})$ (standardized regression weight $=0.93$ ).

3 . The effect of OC on performance (standardized regression weight $=0.95$ ) is positive and significant at $\mathrm{p}<0.05$. The hypothesis of this study is supported.

\subsection{Discussion}

The results of the study provide empirical support to the hypothesis that the performance of construction organizations is positively affected by their organizational cultures. With reference to the standardized regression weights (SRW), Innovation Orientation (IO) and Reward Orientation (RO) are the highest among the eight OC Identifiers. In fact, there is a clear gap between these two SRWs and the other six SRWs. Similarly, in the Performance loop, the SRW of Innovation and Learning (INL) was 0.93 and significantly higher than the next highest of 0.77 for Internal Business Process (IBP). The aforementioned findings suggest that Innovation is the most distinct success factor in terms of both OC and performance.

Positive organizational cultures are those that enable the organization to improve (Alas et al. 2009). Valuable culture is also often unique to the organization and difficult to imitate (Barney 1986). Among the eight OC identifiers, IO and RO can be considered as positive cultural factors as suggested by Barney (1986). Globalization has revolutionized the construction market, changing it from a local industry to one involving international competition, especially for mega projects (Ankrah, Langford 2005). Hartmann (2006a, 2006b) considers an organization that is able to consistently and profitably deliver better services than its competitors as having a real survival edge in the fierce global market (Hartmann 2006a, 2006b). To achieve this, contracting organizations 
should develop culture that can motivate and foster innovative behavior amongst its members. Hartmann (2006a) identified organizational culture as an instrumental vehicle in driving innovation. The pivotal role of innovation in today's business can be evidenced by the success of organizations like Google and Apple. New ideas should not be lost in the organizations hierarchy, nor should creativity be undermined by daily routines. To these ends, a shared value of treasuring innovation within an organization is the survival kit in today's competitive business environment. Construction organizations should also develop a culture of rewarding employees and accepting innovative ideas in order to sustain their performance and competitive advantages. Based on a case study conducted in Switzerland, Hartmann (2006a) identified three managerial actions that construction organizations can take to maintain staff involvement in and dedication to innovation: (1) establishing reward and incentive schemes to recognize innovative staff ideas, (2) allowing staff to take reasonable risks for implementing innovative ideas in operations and (3) providing prompt and positive feedback on the staff proposals for innovative activities. Item (4) neatly brings our discussion to Innovation \& Learning (IL) as a critical performance evaluator. Organizational learning embraces the broad concept of how organizations can learn from their own mistakes and experience in order to improve performance. Wong et al. (2008) identified that double-loop learning is a more effective learning style in terms of performance improvement. It was further suggested that performance-monitoring systems should be designed to facilitate learning.

This study hypothesized that the performance of construction organizations is positively affected by its organizational culture. The final SEM suggests that the structural path from OC to PERF (regression weight $=0.95$ ) was positive and significant as hypothesized (Ankrah, Langford 2005; Liu 1999). Innovation has been singled out as the key cultural factor in terms of driving performance, and is measured by the ability to innovate. Hammer (2004) illustrated how operational innovation allowed an automobile industry to survive and grow in a highly competitive and volatile automobile insurance market. Transformation was underpinned by a belief in keeping the customer satisfied. Operational procedures were constantly reviewed and adjusted to achieve customer satisfaction. Although construction is often identified as a 'conventional' industry that lacks the motivation to innovate, Winch (2003) aptly points out that this inefficiency label is the result of the narrow identification of construction. Taking the construction supply chain as a whole, innovation is occurring no less than in its manufacturing counterpart. Sexton and Barrett (2003) echoed this viewpoint and further suggested that small construction companies can contribute to innovation waves in their respective expertise. The findings of this study add strength to the general belief that cultural factors are having more profound effects on the long-term well being of an organization.

\section{Limitations and recommendations}

This study has a number of limitations. The first is associated with sampling. The data for this study was collected in Hong Kong and thus the findings have to be discussed in this geographical context. Secondly, the 103 valid responses used in this study are con- 
sidered reasonable, although a larger number is preferred. Administrating similar studies in other countries and extending them to other stakeholders within the construction supply chain are therefore suggested. Thirdly, moving from a seven point Likert scale for performance indicators to a numeric scale is preferred but the difficulty in obtaining such data is duly acknowledged. Respondents of managerial capacity are more likely to have exposure and understanding of OC. The respondents for this study were of professional grades and are believe to be able to provide relevant responses for the study. It is also prudent to be mindful of the contingent nature of the influence of organizational culture on performance. The reported study deals with a construction specific situation with construction organizations as subjects, and may not be generalizable.

\section{Concluding remarks}

Construction aspires to be a more efficient industry. A number of industry wide studies have suggested the need to cultivate a culture that is more conducive to business success in construction. This study investigated the relationships between organizational culture and the performance of construction organizations. Construction organizations have been chosen for this study because they are at the production front line in terms of realizing designs into physical objects. Their performance thus has a direct impact on the intended output. OC identifiers and performance indicators were shortlisted from a literature review. These were then translated into operational statements. With data collected from Hong Kong contractors, the OC and Performance constructs were first tested for internal consistency. These two constructs were then linked to form the OC - Performance relationship framework that was tested using Structural Equation Modeling. The SEM results support the use of the eight $\mathrm{OC}$ identifiers for framing $\mathrm{OC}$ in construction and the four performance indicators for evaluating performance. The final $\mathrm{OC}$ - Performance relationship framework indicates a positive relationship between organization culture and performance. Innovation was found to be the most pivotal cultural factor, apparently for its decisive role in supporting creativity. To this end, proper recognition of, and reward for, innovation should be an integral part of performance evaluation. Notwithstanding the wealth of studies in organizational culture, with the respondents being members of construction organizations, this study provides an extended perspective on the impact of project-based organizational culture on the performance of construction organizations.

\section{Acknowledgement}

The work described in this paper is fully supported by a grant from the City University of Hong Kong (Project No. 7002086) and a HKSAR RGC General Research Fund (Project No. 112008). 
S. O. Cheung et al. An investigation of the relationship between organizational culture and the performance ...

\section{References}

Alas, R.; Kraus, A.; Niglas, K. 2009. Manufacturing strategies and choices in culture contexts, Journal of Business Economics and Management 10(4): 279-289.

http://dx.doi.org/10.3846/1611-1699.2009.10.279-289

Amaratunga, D.; Baldry, D.; Sarshan, M. 2001. Process improvement through performance measurement: the balanced scorecard methodology, Work Study 50(5): 179-188.

http://dx.doi.org/10.1108/EUM0000000005677

Ankrah, N. A.; Langford, D. A. 2005. Architects and contractors: a comparative study of organizational cultures, Construction Management and Economics 23(6): 595-607.

http://dx.doi.org/10.1080/01446190500126973

Arbuckle, J. L.; Wothke, W. 1999. Amos 4.0 User's Guide. Small Waters Corporation, USA.

Barney, J. 1986. Strategic factor markets: expectations, luck, and business strategy, Management Science 32(10): 1231-1241. http://dx.doi.org/10.1287/mnsc.32.10.1231

Bayliss, R.; Cheung, S. O.; Suen, C. H. H.; Wong, S. P. 2004. Effective partnering tools in construction: a Case Study on MTRC TKE Contract 604 in Hong Kong, International Journal of Project Management 22(3): 253-263. http://dx.doi.org/10.1016/S0263-7863(03)00069-3

Bresnen, M.; Marshall, N. 2000. Motivation, commitment and the use of incentives in partnerships and alliances, Journal of Construction Management and Economics 18(5): 587-598.

http://dx.doi.org/10.1080/014461900407392

Butler, J. K. 1991. Toward understanding and measuring conditions of trust: evolution of a conditions of trust inventory, Journal of Management 17(3): 643-665.

http://dx.doi.org/10.1177/014920639101700307

Cameron, K. S.; Quinn, R. E. 1999. Diagnosing and Changing Organizational Culture Based on the Competing Values Framework. Addison-Wesley, Reading, U.K.

Cheng, C. W. M.; Liu, A. M. M. 2007. The relationship of organizational culture and the implementation of total quality management in construction firms, Surveying and Build Environment 18(1): 7-16.

Cheung, S. O.; Wong, S. P.; Wu, W. Y. 2010. Towards an organizational culture framework in construction, International Journal of Project Management 29(1): 33-44.

http://dx.doi.org/10.1016/j.ijproman.2010.01.014

Cole, G. A. 1997. Personnel Management. 4th ed. Letts Educational, London.

Construction Industry Review Committee of Hong Kong (CIRC). 2001. Construct for excellence. Construction Industry Review Committee, Hong Kong.

Cummings, L. L.; Bromiley, P. 1996. The Organizational Trust Inventory, in Kramer, R.; Tyler, T. (Eds.). Trust in Organisation. Frontier of Theory and Research, Sage Publications.

Denison, D. R. 1990. Corporate Culture and Organizational Effectiveness. Wiley, New York.

Egan, J. 1998. Rethinking Construction. Department of the Environment, Transport and the Region HMSO, London.

Gordon, G. G.; DiTomaso, N. 1992. Predicting corporate performance from organizational culture, Journal of Management Studies 29: 783-798. http://dx.doi.org/10.1111/j.1467-6486.1992.tb00689.x

Hair, J. F.; Anderson, R. E.; Tatham, R. L.; Black, W. C. 1998. Multivariate Data Analysis. 5th ed. Patience Hall, New Jersy.

Hammer, M. 2004. Deep change: how operational innovation can transform your company, Harvard Business Review 82(9): 85-93. 
Hartmann, A. 2006a. The role of organizational culture in motivating innovative behaviour in construction firms, Construction Innovation 6(3): 159-172.

http://dx.doi.org/10.1108/14714170610710712

Hartmann, A. 2006b. The context of innovation management in construction firms, Construction Management and Economics 24(6): 567-578. http://dx.doi.org/10.1080/01446190600790629

Hofstede, G. 2001. Culture's Consequences: Comparing Values, Behaviors, Institutions, and Organizations Across Nations. Sage Publications, London.

Jöreskog, K.; Sörbom, D. 1996. LISREL 8: Users Reference Guide. Hillsdale, Lawrence Erlbaum Associates, New Jersy.

Kagioglou, M.; Cooper, R.; Aouad, G. 2001. Performance management in construction: a conceptual framework, Construction Management and Economics 19(1): 85-95.

http://dx.doi.org/10.1080/01446190010003425

Kaplan, R. S.; Norton, D. P. 1992. The Balanced Scorecard: measures that drive performance, Harvard Business Review 70(1): 71-79.

Kululanga, G. K.; Edum-Fotwe, F. T.; McCaffer, R. 2001. Measuring construction contractors' organizational learning, Building Research and Information 29(1): 21-29.

http://dx.doi.org/10.1080/09613210150208769

Law, K. M. Y.; Chuah, K. B. 2004. Project-based action as learning approach in learning organization: the theory and framework, Team Performance Management 10(7/8): 178-186. http://dx.doi.org/10.1108/13527590410569904

Liu, A. M. 1999. Culture in the Hong Kong real-estate profession: a trait approach, Habitat International 23(3): 413-425. http://dx.doi.org/10.1016/S0197-3975(99)00015-6

Mohamed, S. 2003. Scorecard approach to benchmarking organizational safety culture in construction, Journal of Construction Engineering and Management ASCE 129(1): 80-88. http://dx.doi.org/10.1061/(ASCE)0733-9364(2003)129:1(80)

Molenaar, K.; Washington, S.; Diekmann, J. 2000. Structural equation model of construction contract dispute potential, Journal of Construction Engineering and Management 126(4): 268-277. http://dx.doi.org/10.1061/(ASCE)0733-9364(2000)126:4(268)

Ozorhon, B.; Arditi, D.; Dikmen, I.; Birgonul, M. T. 2008. Implications of culture in the performance of international construction joint ventures, Journal of Construction Engineering and Management ASCE 134(5): 361-370. http://dx.doi.org/10.1061/(ASCE)0733-9364(2008)134:5(361)

Peters, T. J.; Waterman, R. H. 1982. In Search of Excellence: Lessons from America's Best-run Companies. Harper and Row, New York.

Schein, E. H. 1985. Organizational Culture and Leadership: A Dynamic View. Jossey-Bass, San Francisco, USA.

Sexton, M.; Barrett, P. 2003. Appropriate innovation in small construction firms, Construction Management and Economics 21(6): 623-633. http://dx.doi.org/10.1080/0144619032000134156

Sharma, S. 1996. Applied Multivariate Techniques. John Wiley \& Sons, USA, 116-123.

Smircich, L. 1983. Concepts of culture and organizational analysis, Admin. Sci. Quart. 28: 339358. http://dx.doi.org/10.2307/2392246

Winch, G. M. 2003. How innovative is construction? Comparing aggregated data on construction innovation and other sectors - a case of apples and pears, Construction Management and Economics 21(6): 651-654. http://dx.doi.org/10.1080/0144619032000113708

Wong, P. S. P.; Cheung, S. O.; Leung, K. Y. 2008. The moderating effect of organizational learning type on performance improvement, Journal of Management in Engineering 24(3): 162-172. http://dx.doi.org/10.1061/(ASCE)0742-597X(2008)24:3(162) 
Xiao, H.; Proverbs, D. 2003. Factors influencing contractor performance: an international investigation, Engineering Construction and Architectural Management 10(5): 322-332. http://dx.doi.org/10.1108/09699980310502937

Zeng, S. X.; Xie, X. M.; Tam, C. M.; Sun, P. M. 2009. Identifying cultural difference in R\&D project for performance improvement: a field study, Journal of Business Economics and Management 10(1): 61-70. http://dx.doi.org/10.3846/1611-1699.2009.10.61-70

Zhang, S. B.; Liu, M. M. 2006. Organizational culture profiles of construction enterprises in China, Construction Management and Economics 24(8): 817-828.

http://dx.doi.org/10.1080/01446190600704604

Sai On CHEUNG is the Director of the Construction Dispute Resolution Research Unit (CDRRU) of the Department of Civil and Architectural Engineering, City University of Hong Kong. He has published widely in the areas of dispute management and organization behavior in construction.

Peter S. P. WONG is a senior lecturer of the School of Property, Construction and Project Management at RMIT University, Melbourne, Australia. He obtained the Ph.D. in the City University of Hong Kong. Dr Wong has developed a research portfolio that addresses key issues in construction economics and management. These include organizational culture and organisational learning.

Anna L. LAM is a graduate in BSc (Hons) in Surveying of the City University of Hong Kong. She is an active researcher in construction management. Her research interests include performance measurement and organizational culture. 